\title{
Experimental Research on the Tribological -Mechanical Properties of Al-SiC composites and EN31 Steel
}

\author{
D. Ramesh, V. R. Muruganantham, K. Arun Balasubramanian, A. Thirumoorthy,
}

\section{Sudhakar}

\begin{abstract}
In this research, metal matrix composites was fabricated using stir cast technique. Al 6061 alloy (Matrix) and silicon carbide (Reinforcement) were selected as particles. Tata Ace (mini truck) frame made of EN31 steel considered as a comparative material. Optimal weight \% of SiC particles was selected as $30 \%$. Tensile, impact, hardness tests and tribological behaviour of the fabricated composites and EN31 steel was carried out. The mechanical tests such as tensile, impact and hardness are conducted according to the ASTM standards. The results shows that the fabricated composites had improved properties when compared to EN31 steel.
\end{abstract}

Keywords : SiC particles, Metal matrix composite, Stir casting, carbon steel EN31.

\section{INTRODUCTION}

THE Automotive chassis is a skeletal frame on which the components like engine block, axle assemblies, and steering etc, are mounted [1]. Automobile chassis is the structural element which holds the automobile rigid, stiff and unbending. A rigid chassis ensures minimal noise, vibrations and harshness for the entire automobile. The skeleton is the most vital component that invigorates and solidness to the vehicle under stacking conditions [2]. The field of composite materials are broadly characterized into polymer network, metal lattice and clay framework composites. The lattice holds the dominant part "delicate" stage (normally pliable, greater formability and high warm conductivity) to which installed the "hard" fortifications (high solidness and low warm expansion) [3]. The support stage can be utilized in nonstop or spasmodic, orientated or disorientated way as indicated by the application. Aluminum finds wide application in basic material particularly in the aeronautic

Revised Manuscript Received on December 30, 2019.

* Correspondence Author

D. Ramesh*, Department of Mechanical Engineering, Rathinam Technical Campus, Coimbatore - 641021, Tamil Nadu, India.

Email: rameshdsm@gmail.com

V R Muruganantham, Faculty of Mechanical Engineering, Kumaraguru

College of Technology, Coimbatore - 641049, Tamil Nadu, India.

Email: muruganantham.vr.mec@kct.ac.in

K. Arun Balasubramanian, Department of Mechanical Engineering, Sethu Institute of Technology, Virudhunagar - 626115, Tamil Nadu, India.

Email: kabmech@gmail.com

A.Thirumoorthy, Department of Mechanical Engineering, Rathinam Technical Campus, Coimbatore - 641021, Tamil Nadu, India.

Email: atmmech32@gmail.com

M. Sudhakar, Department of Mechanical Engineering, Sri Sairam Engineering College, Chennai-600044.

Email: sudhakar.mech@sairam.edu.in

(C) The Authors. Published by Blue Eyes Intelligence Engineering and Sciences Publication (BEIESP). This is an open access article under the CC BY-NC-ND license (http://creativecommons.org/licenses/by-nc-nd/4.0/) trade as a result of its light weight property [4-6]. Be that as it may, the low quality and low liquefying point finds troublesome in presenting to significant applications [7-9]. A wide acknowledged technique for taking care of this issue was the utilization of support particles, for example, $\mathrm{SiO}_{2}$, $\mathrm{SiC}, \mathrm{B}_{4} \mathrm{C}$ particles, carbon fiber, glass fiber/stubbles or different components or mixes as alloying component [10].

\section{MATERIALS AND METHODS}

\section{A. Al6061 alloy as matrix material}

Composites were manufactured using $\mathrm{Al} 6010$ alloy as shown in Fig. 1 used as the matrix and $\mathrm{SiC}$ particles as the reinforcement. The physical and mechanical properties of $\mathrm{Al}$ 6061 alloy is given in the Table. I \& II. Pure Aluminum has greater affinity for oxygen; this results in the creating a very thin but tenacious oxide film which covers the surface when exposed to the atmosphere [11].

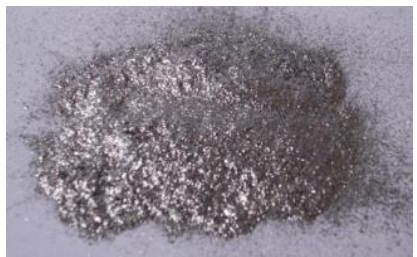

Fig. 1. Aluminum alloy (Al 6061)

Table- I: Physical properties of Al 6061

\begin{tabular}{|c|c|}
\hline Densitylb bin ${ }^{3}$ & 0.0975 \\
\hline Thermal Conductivity, Btu-inh/hrofflo. of & 1160 \\
\hline Electrical Resistivity, I-cm & $3.99 \mathrm{e}-006$ \\
\hline Spectic Glavity & 2.7 \\
\hline Melting Point (DegF) & 1090 \\
\hline Modules of Elasticity in Tension & 10 \\
\hline Modules of elasticity in Torsion & 3.8 \\
\hline
\end{tabular}

Table-II Mechanical properties of Al 6061

\begin{tabular}{|l|l|}
\hline & \\
\hline Ultimate Tensile Strength & 45,000 \\
\hline Tensile Yield Strength & 40,000 \\
\hline Elongation at Break & $12 \%$ \\
\hline Hardness, Rockwell B & 60 \\
\hline Modules of Elasticity, ksi & 10,000 \\
\hline
\end{tabular}

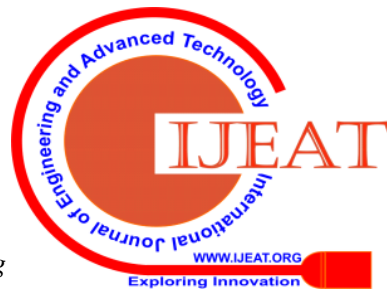


Silicon Carbide is made out of tetrahedral of carbon and silicon particles with solid bonds in the precious stone cross section. Thickness of SiC was $3.1 \mathrm{~g} / \mathrm{cm}^{3}$ and normal molecule size of $20 \mu \mathrm{m}$. It is extremely hard and solid material [12]. $\mathrm{SiC}$ when heated to $1200{ }^{\circ} \mathrm{C}$, an oxide layer is deposited on the particles and these particles can be operated up to a temperature of $1600^{\circ} \mathrm{C}$. Silicon carbide pottery with next to zero grain limit polluting influences keep up their solidarity to high temperatures, moving toward $1600^{\circ} \mathrm{C}$ with no quality misfortune.

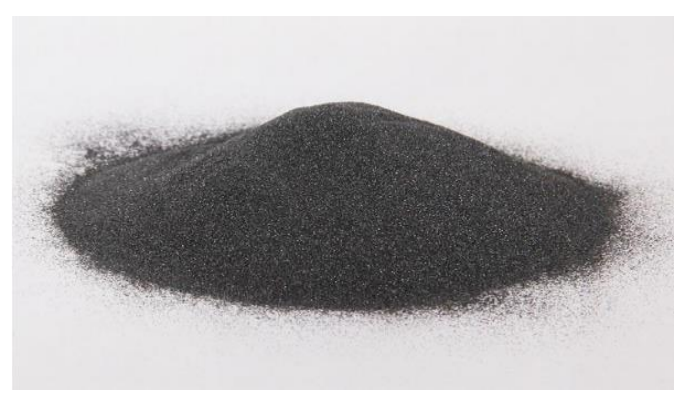

Fig. 2. Silicon carbide powder

\section{B. Stir casting of composite}

Manufacture strategies influence the microstructure, dispersion of the fortifying materials and interfacial security among network and fortification. During creation it is must to guarantee uniform circulation of the fortification in the network and arrangement of good bond among lattice and strengthening material, to accomplish ideal properties. There are a few manufacture methods, for example, mix cast, press cast [13], diffusive cast, reho cast, vacuum cast and powder metallurgy are accessible for creating MMC's. The creation strategies can be separated into three sorts, for example, (I) strong stage process, (ii) fluid stage procedure and (iii) semi-strong procedure. Among the assortment of assembling forms accessible for spasmodic metal grid composite, mix giving is commonly acknowledged a role as an especially encouraging course, as a result of minimal effort. Lie in its effortlessness, adaptability and materialness to the huge amount generation. Mix cast enables extremely enormous measured parts to be created, and can continue high efficiency rates. The expense of planning composite materials utilizing mix cast technique is around $33 \%$ to one a large portion of that of contending strategies. Fig. 3 shows the pictorial chart of the mix cast arrangement.

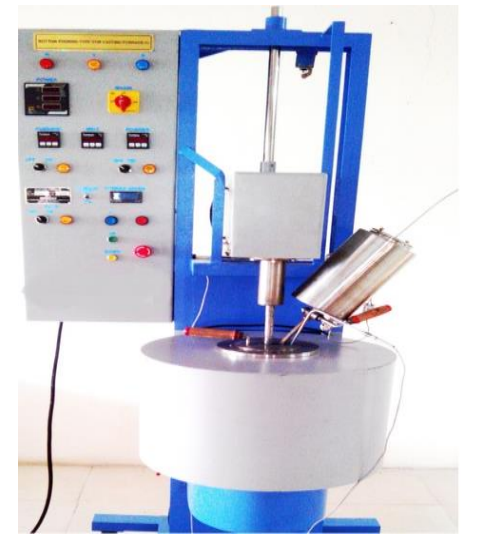

Fig. 3. Stir Casting Equipment

Obstruction heater with a temperature scope of $3000{ }^{\circ} \mathrm{C}$ was utilized to dissolve the grid material. The heater has a temperature controller with $\mathrm{k}$ type thermocouple to control and quantify the temperature. An electric engine is fixed at the top edge of the heater to give mixing movement to the stirrer. The speed of the stirrer can be shifted as the arrangement has a speed controller connected to it.

Aluminum compound 6061 is sliced and weighed to get the right weight according to the stoichiometric figurings. The compound is then taken into a pot alongside the Kavaral. The heater is warmed to a temperature of $800{ }^{\circ} \mathrm{C}$ and is continually kept up at that temperature all through the procedure. Warming the support particles before scattering into the soften helps their exchange by causing desorption of adsorbed gases from the molecule surface. Silicon carbide particles are warmed to $1000{ }^{\circ} \mathrm{C}$. Preheating of SiC particles expels surface polluting and modifies the surface synthesis by shaping an oxide layer superficially. The expansion of pre-warmed $\mathrm{SiC}$ particles in $\mathrm{Al}$ soften has been found to improve the wettability property. Kavaral is the creation of Potassium chloride $(\mathrm{KCl})+$ Nitric corrosive $\left(\mathrm{HNO}_{3}\right)$, its capacity is to evade oxidation. The prescribed sum that will be included is $250 \mathrm{gm}$ for the matrix melt of $50 \mathrm{~kg}$.

\section{Addition of Degasser powder}

Degasser powder reduces blow holes formed during the casting process. The reasons for adding degasser powder are as below when magnesium is in the molten state, it tries to absorb hydrogen from the atmosphere. When the absorbed hydrogen is unable to escape from the molten metal, it results in the formation of blow holes. When coverall 65 is added, it forms a thin film over the molten metal and prevents contact of molten metal with the atmosphere. When degasser tablets is added to molten metal, the chlorine present in these tablets react with hydrogen in the molten metal and form hydrochloric acid which dissolves in the molten metal, thereby reducing blow holes.

\section{Pouring of matrix melt}

The melt is mixed at a speed of $300 \mathrm{rpm}$ for thirty minutes using a mechanical operated stirrer. The mixed metal is then gradually filled the bite the dust which is preheated to a temperature of $973^{\circ} \mathrm{C}$. The pass on is permitted to cool in air for two hours and afterward the example is expelled.

\section{E. Solution Treatment}

During throwing low cooling pace of the amalgam takes into consideration the reinforcing of aluminum eliminate to accelerate of arrangement and develop into enormous incongruous stages inside the network. In the as cast structure, the enormous in cognizant nature of the Al-SiC [14] stage does little to build the quality of the compound. To get finely scattered an answer heat treatment ought to be directed on the combination.

\section{F. Composite Preparation}

The hardness of arranged composites was expanded by expanding silicon content. Expansion of graphite particles in aluminum network can prompt production of financial composites with improved hardness. These composites can discover application in car like cylinder, cylinder liners and associating bars. These composites can likewise discover application where light-weight materials are required with great hardness and quality [15].

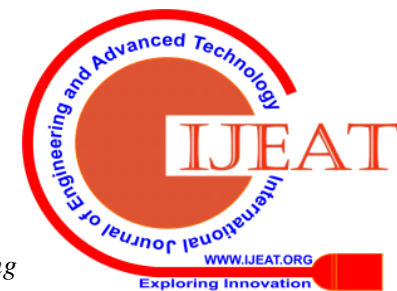




\section{MECHANICAL PROPERTIES AFTER TESTING}

\section{A. Brinell hardness and wear test}

Mass hardness estimations were completed on the base metal and fabricated composite specimen by utilizing standard Brinell hardness test machine. Tests utilized for the hardness tests are displayed in Fig 4. The pin-on-disc setup used for wear tests is shown in Fig.5. The test parameters and values are displayed in Table-III.

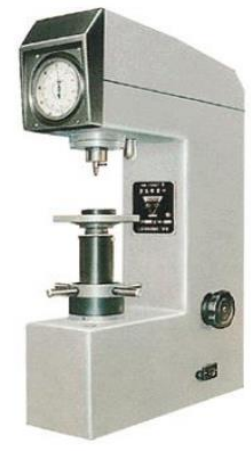

Fig. 4. Hardness Test Setup

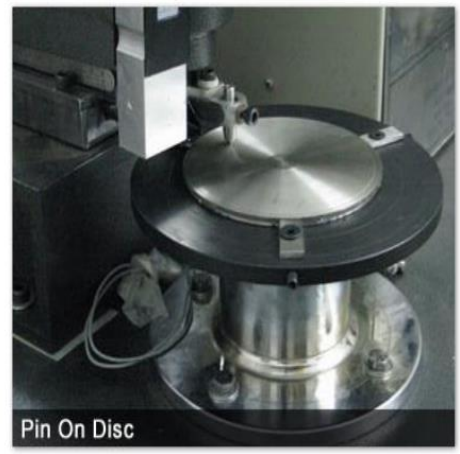

Fig. 5. Wear Test Setup
Table-III: Linear reciprocating setup for both materials

\begin{tabular}{|l|l|l|}
\hline Sl. No & \multicolumn{1}{|c|}{ Test parameters } & \multicolumn{1}{c|}{ Value } \\
\hline 1 & Normal force & $20 \mathrm{~N}, 40 \mathrm{~N}$ \\
\hline 2 & Wear track length & $12 \mathrm{~mm}$ \\
\hline 3 & Speed & 200 cycles/min \\
\hline 4 & Revolutions & 2500 \\
\hline 5 & Pin geometry circular & $\Phi 6 \mathrm{~mm}$ \\
\hline 6 & Pin material & $\mathrm{Al}$ \\
\hline
\end{tabular}

\section{B. Tensile test}

The presence of $\mathrm{SiO}_{2}$ composition in the Metal Matrix Composite have resulted in a slight increase in the tensile behavior of the composite. The Tensile test setup displayed in Fig. 6 and test values are shown in graph below. It is inferred that the addition of $\mathrm{SiO}_{2}$ increases the Hardness since the moving dislocation in the Aluminium which usually would favours it being ductile in its pure form has now been occupied by the fine Silicon di-Oxide. On the other hand, the yield point also lowers considerably. It can be observed that the graph after the yield point breaks abruptly at a point lower than it leading to failure if the material. Had it been in its pure form, the Aluminium would have shown higher yield point and be less brittle. Silicon di-Oxide has increased the hardness of the composite which favours its utilization in the heat affected zones of the automotive equipment's.

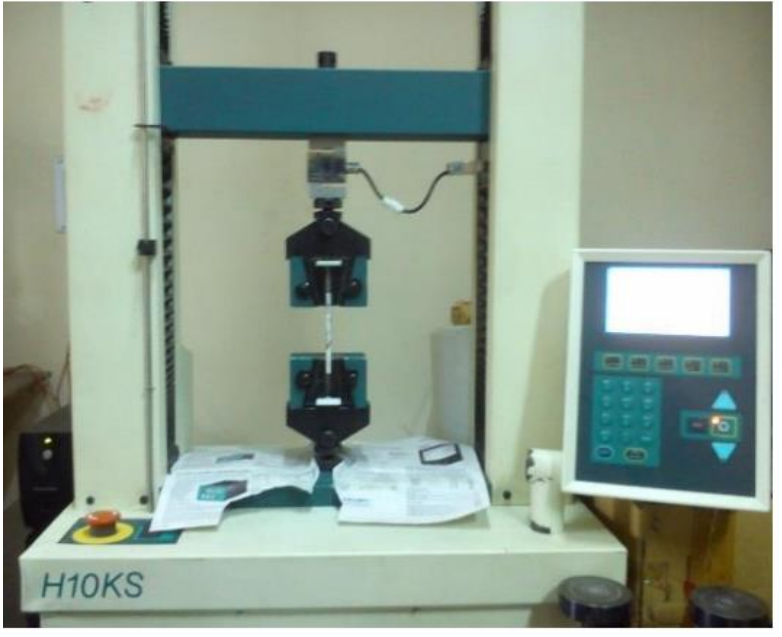

Fig. 6. Universal testing machine - Tinius Olsen H10KS

\section{RESULT AND COMPARISON}

\section{A. Brinell Hardness}

The Hardness Test value comparison between Al-SiC [1] (Composite material) and Carbon steel (Existing material) is tabled and graphed below.

Table-I: IV Hardness test results

\begin{tabular}{|l|l|l|l|l|}
\hline $\begin{array}{l}\text { SI. } \\
\text { No }\end{array}$ & \multicolumn{1}{|c|}{ Material } & $\begin{array}{c}\text { Indenter dia } \\
\text { in (mm) }\end{array}$ & $\begin{array}{c}\text { Load } \\
\text { in kgf }\end{array}$ & $\begin{array}{l}\text { Hardnes } \\
\text { s (BHN) }\end{array}$ \\
\hline 1 & $\begin{array}{l}\text { Al-SiC[1] } \\
\text { (Composite) }\end{array}$ & $\begin{array}{l}\text { Steel sphere } \\
5 \mathrm{~mm}\end{array}$ & 100 & 48.3 \\
\hline 2 & $\begin{array}{l}\text { Carbon steel } \\
\text { EN31[2] }\end{array}$ & $\begin{array}{l}\text { Steel sphere } \\
5 \mathrm{~mm}\end{array}$ & 100 & 35 \\
\hline
\end{tabular}

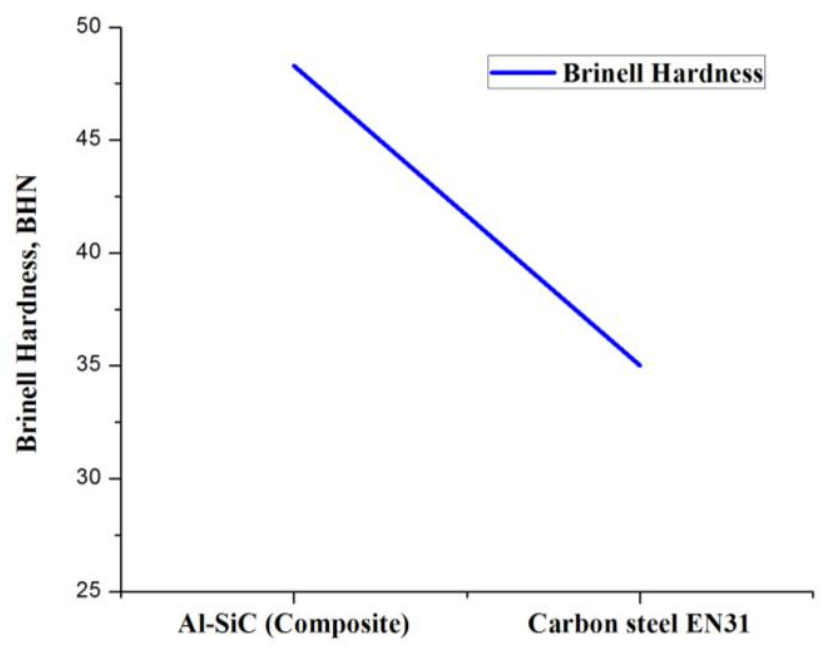

Graph -1 hardness test results

\section{B. Impact strength}

The Impact strength value comparison between Al-SiC (Composite material) and Carbon steel.

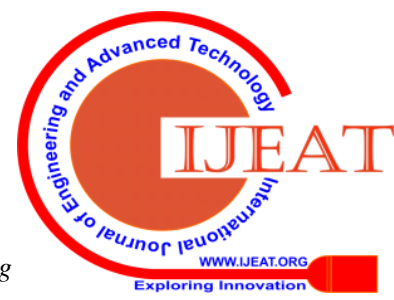


Impact strength

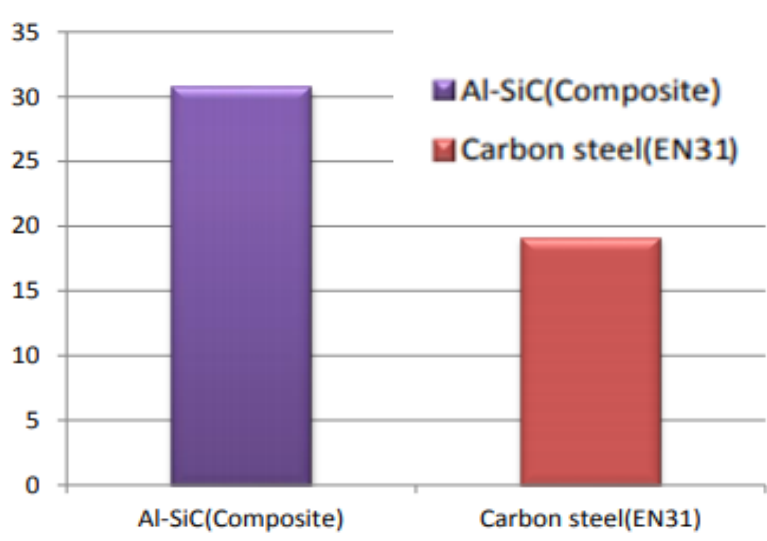

Graph -2 impact strength test results

\section{Tensile test}

The Tensile test value comparison between Al-SiC (Composite) and Carbon steel (Existing material) is tabled and graphed below.

Table-V: Tensile test results

\begin{tabular}{|c|c|c|c|c|}
\hline $\begin{array}{l}\text { SI. } \\
\text { No }\end{array}$ & Material & $\begin{array}{l}\text { Cross section } \\
\text { of area }\left(\mathrm{mm}^{2}\right)\end{array}$ & $\begin{array}{l}\text { Ultimat } \\
\text { e load in } \\
(\mathrm{KN})\end{array}$ & $\begin{array}{l}\text { Tensile } \\
\text { strength } \\
\left(\mathrm{N} / \mathrm{mm}^{2}\right)\end{array}$ \\
\hline 1 & $\begin{array}{l}\text { Al-SiC[1] } \\
\text { (Composite) }\end{array}$ & 490.87 & 13.360 & 184.93 \\
\hline 2 & $\begin{array}{l}\text { Carbon steel } \\
\text { (EN31[2]) }\end{array}$ & 490.87 & 22.5 & 181 \\
\hline
\end{tabular}

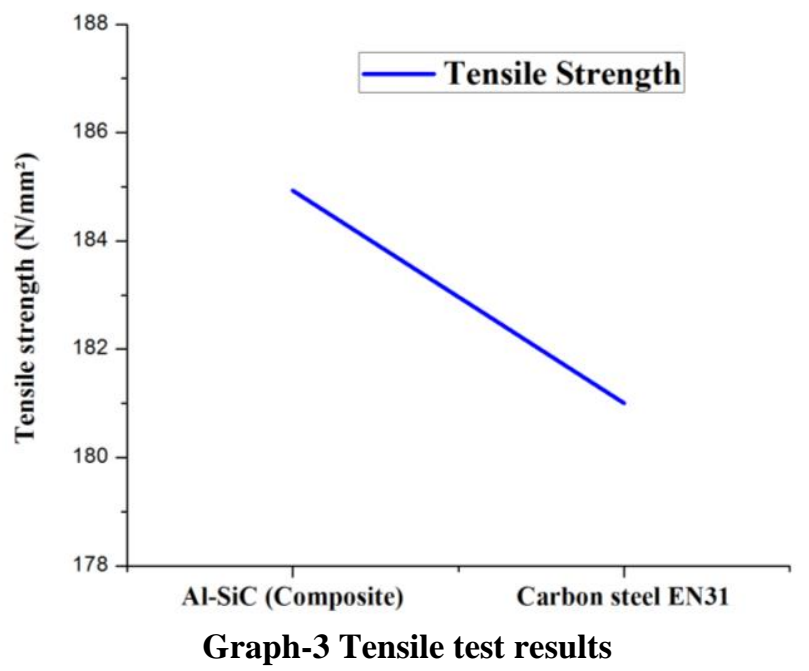

\section{Wear Test}

The wear test value comparison between Al-SiC (Composite material) and Carbon steel (Existing material) is tabled and graphed below.

Table-VI: Wear test results

\begin{tabular}{|c|c|c|c|c|}
\hline $\begin{array}{l}\text { SI. } \\
\text { No }\end{array}$ & Material & $\begin{array}{l}\text { Sliding } \\
\text { speed } \\
(\mathrm{m} / \mathrm{s})\end{array}$ & $\begin{array}{l}\text { Load } \\
(\mathrm{N})\end{array}$ & $\begin{array}{l}\text { Wear rate } \\
\left(\mathrm{mm}^{3} / \mathrm{m}\right)\end{array}$ \\
\hline \multirow{2}{*}{1} & $\begin{array}{l}\mathrm{Al}-\mathrm{SiC}[1] \\
\text { (composite) }\end{array}$ & 2 & 20 & 0.0024 \\
\hline & $\begin{array}{l}\text { Al-SiC[1] } \\
\text { (composite) }\end{array}$ & 2 & 40 & 0.0027 \\
\hline \multirow[t]{2}{*}{2} & $\begin{array}{ll}\text { Carbon } & \text { steel } \\
(\text { EN31[2]) } & \\
\end{array}$ & 2 & 20 & 0.0072 \\
\hline & Carbon steel & 2 & 40 & 0.0096 \\
\hline
\end{tabular}

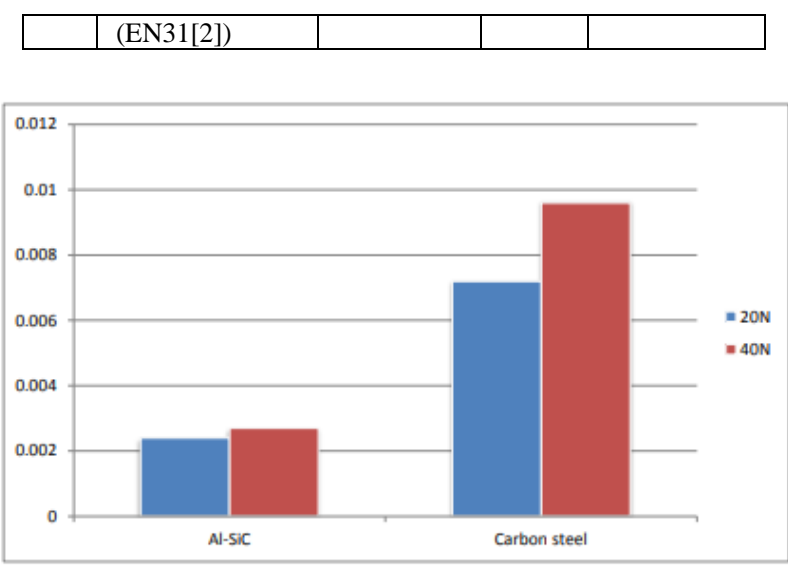

Graph -4 Wear test results

\section{CONCLUSION}

This investigation and analysis of the frame made up $\mathrm{Al}-\mathrm{SiC}$ is providing better results comparatively. The outcome delineates that the hardness and rigidity of Al-SiC is higher contrasted with EN31.we can utilize aluminum silicon carbide for outline because of its light weight and high quality. In this manner it is a light weight it builds the eco-friendliness of the vehicle than the current carbon steel EN31 material casing.

\section{REFERENCES}

1. M. D. Vijayakumar, et.al., Mat Today:Proc., https://doi.org/10.1016/j.matpr.2019.07.741.

2. T. Adithiyaa et.al.,, Mat Today: Proc:, https://doi.org/10.1016/j.matpr.2019.07.711.

3. K. Gurusami, D. et al., Mat Today: Proc. https://doi.org/10.1016/j.matpr.2019.09.141.

4. K Gurusami, et.al. (2019): Int. J. Amb. Energy, DOI 10.1080/01430750.2019.1614987.

5. Sathish,T. IJMPERDSPL201883, 2018, pp. 705-710.

6. Sathish, T. IJRTE, Volume 7 (6), 2019, pp. 281-286.

7. D Chandramohan, Acad. J. of Mfg. Eng.,12(3),2014, pp. 72-77.

8. D Chandramohan, Acad. J. of Mfg. Eng.,12(3),2014, pp. 67-71.

9. Sathish, T. IJRTE, Volume 7 (6), 2019, pp. 287-290.

10. Dhanashekar, M., et.al. Materiali in tehnologije / Materials and technology, doi:10.17222/mit.2018.038.

11. Dhanashekar, M., Senthil Kumar, VS, Tribological behaviour of squeeze cast $\mathrm{Al}-\mathrm{Si} 7 \mathrm{Mg} / \mathrm{SiC} / \mathrm{Gr}$ hybrid composites, Journal of the Balkan Tribological Association, 24(1), 2018, pp. 106-121.

12. Dhanashekar, M., Senthil Kumar, VS, Materials Science (MEDŽIAGOTYRA), https://doi.org/10.5755/j01.ms.25.3.20442.

13. Senthil Kumar, VS., Dhanashekar, M., Karthikeyan, S, "Investigation of process parameters on dry sliding wear of self-lubricating metal matrix composites" ASME-IMECE, vol.12, 2018.

14. Mukilan. B, Arun Kumar. J, M. Dhanashekar, "Tribology Studies in Powder Metallurgy AL-LM13 SiC Reinforced Functionally Graded Composites", International Journal of Advanced Research Trends in Engineering and Technology (IJARTET), 4(19), 2017, pp. 523-536.

15. M. Dhanashekar, V. S. Senthil Kumar, Procedia Engineering, https://doi.org/10.1016/j.proeng.2014.12.265. 


\section{AUTHORS PROFILE}

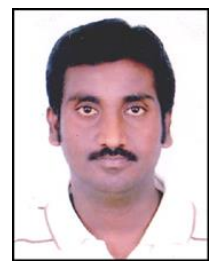

Mr.D.Ramesh, Working as Faculty of Mechanical Engineering, Rathinam Technical Campus, Coimbatore - 641021, Tamil Nadu, India He has got teaching experience of more than 6 years and he has published various national and international journals.

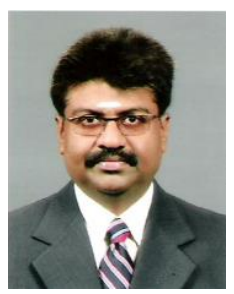

Dr.V R Muruganantham, Working as Faculty of Mechanical Engineering, Kumaraguru College of Technology, Coimbatore - 641049, Tamil Nadu, India

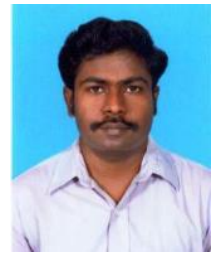

Dr.K. Arun Balasubramanian , Working as Faculty of Mechanical Engineering, Sethu Institute of Technology, Virudhunagar 626115, Tamil Nadu, India

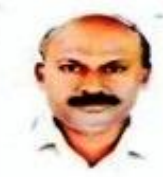

Mr.A.Thirumoorthy, Working as Faculty of Mechanical Engineering, Rathinam Technical Campus, Coimbatore - 641021, Tamil Nadu, India.

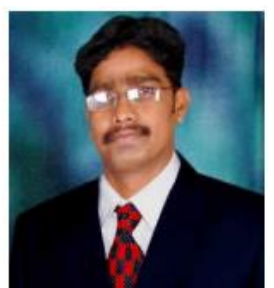

M. Sudhakar working as Assistant Professor of Mechanical Engineering in Sri Sairam Engineering College, Chennai. He has teaching experience of more than 06 Years and 02 years of Industrial Experience; his field of interest is Composites, Energy Engineering and Dynamics of Machines. He published various international Journals of repute in Scopus Indexed Journals. 